Caries Excavation: Evolution of Treating Cavitated Carious Lesions 


\section{Monographs in Oral Science}

Vol. 27

Series Editors
A. Lussi Bern
M.A.R. Buzalaf São Paulo 


\section{Caries Excavation: Evolution of Treating Cavitated Carious Lesions}

Volume Editors

Falk Schwendicke Berlin

Jo Frencken Nijmegen

Nicola Innes Dundee

69 figures, 59 in color, and 19 tables, 2018 
Falk Schwendicke

Operative and Preventive Dentistry

Charité - Universitätsmedizin Berlin

Corporate Member of Freie Universität Berlin

Humboldt-Universität zu Berlin

DE-14197Berlin (Germany)
Jo Frencken

Radboud University Medical Centre Department of Oral Function and Prosthetic Dentistry NL-6525 AX Nijmegen (The Netherlands)

\author{
Nicola Innes \\ School of Dentistry, University of Dundee \\ 2 Park Place \\ Dundee DD1 4HR (UK)
}

Library of Congress Cataloging-in-Publication Data

Names: Schwendicke, Falk, editor. | Frencken, Jo, 1950- editor. | Innes,

Nicola, editor.

Title: Caries excavation : evolution of treating cavitated carious lesions /

volume editors, Falk Schwendicke, Jo Frencken, Nicola Innes.

Other titles: Monographs in oral science ; v. 27.0077-0892

Description: Basel ; New York : Karger, 2018. | Series: Monographs in oral

science, ISSN 0077-0892; vol. 27 | Includes bibliographical references and indexes.

Identifiers: LCCN 2018017608| ISBN 9783318063684 (hbk. : alk. paper) |ISBN

9783318063691 (e-ISBN)

Subjects: | MESH: Dental Caries--therapy | Dental Restoration, Permanent |

Pit and Fissure Sealants--therapeutic use

Classification: LCC RK331 | NLM WU 270 | DDC 617.6/7--dc23 LC record available at

https://lccn.loc.gov/2018017608

Bibliographic Indices. This publication is listed in bibliographic services, including Current Contents ${ }^{\circledR}$ and Index Medicus.

Disclaimer. The statements, opinions and data contained in this publication are solely those of the individual authors and contributors and not of the publisher and the editor(s). The appearance of advertisements in the book is not a warranty, endorsement, or approval of the products or services advertised or of their effectiveness, quality or safety. The publisher and the editor(s) disclaim responsibility for any injury to persons or property resulting from any ideas, methods, instructions or products referred to in the content or advertisements.

Drug Dosage. The authors and the publisher have exerted every effort to ensure that drug selection and dosage set forth in this text are in accord with current recommendations and practice at the time of publication. However, in view of ongoing research, changes in government regulations, and the constant flow of information relating to drug therapy and drug reactions, the reader is urged to check the package insert for each drug for any change in indications and dosage and for added warnings and precautions. This is particularly important when the recommended agent is a new and/or infrequently employed drug.

All rights reserved. No part of this publication may be translated into other languages, reproduced or utilized in any form or by any means electronic or mechanical, including photocopying, recording, microcopying, or by any information storage and retrieval system, without permission in writing from the publisher.

(c) Copyright 2018 by S. Karger AG, P.O. Box, CH-4009 Basel (Switzerland)

www.karger.com

Printed on acid-free and non-aging paper (ISO 9706)

ISSN 0077-0892

e-ISSN 1662-3843

ISBN 978-3-318-06368-4

e-ISBN 978-3-318-06369-1 


\title{
Contents
}

\author{
VII List of Contributors \\ IX Foreword \\ Kidd, E. (London) \\ x Preface \\ Schwendicke, F. (Berlin); Frencken, J. (Nijmegen); Innes, N. (Dundee)
}

The Philosophical Evolution

1 Pathophysiology of Dental Caries

Conrads, G. (Aachen); About, I. (Marseille)

11 Caries Epidemiology and Its Challenges

Frencken, J. (Nijmegen)

24 Carious Lesion Diagnosis: Methods, Problems, Thresholds

Neuhaus, K.W.; Lussi, A. (Bern)

32 Removing or Controlling? How Caries Management Impacts on the Lifetime of Teeth

Schwendicke, F. (Berlin); Lamont, T.; Innes, N. (Dundee)

42 Restoring the Carious Lesion

Göstemeyer, G.; Schwendicke, F.; Blunck, U. (Berlin)

Principles and Options for Treating Cavitated Lesions

56 Removing Carious Tissue: Why and How?

Schwendicke, F. (Berlin)

68 Stepwise Excavation

Bjørndal, L. (Copenhagen)

82 Selective Removal of Carious Tissue

Ricketts, D.; Innes, N. (Dundee); Schwendicke, F. (Berlin)

92 Atraumatic Restorative Treatment: Restorative Component

Leal, S. (Brasília); Bonifacio, C. (Amsterdam); Raggio, D. (São Paulo); Frencken, J. (Nijmegen)

103 Sealing Carious Tissue Using Resin and Glass-Ionomer Cements

Fontana, M. (Ann Arbor, Ml); Innes, N. (Dundee)

113 Sealing Carious Tissue in Primary Teeth Using Crowns: The Hall Technique

Santamaría, R.M. (Greifswald); Innes, N. (Dundee) 
124 No Removal and Inactivation of Carious Tissue: Non-Restorative Cavity Control van Strijp, G.; van Loveren, C. (Amsterdam)

Making the Evolution Happen

137 Evidence-Based Deep Carious Lesion Management: From Concept to Application in Everyday Clinical Practice

Doméjean, S. (Clermont-Ferrand); Grosgogeat, B. (Lyon)

146 The Problem: Relevance, Quality, and Homogeneity of Trial Designs, Outcomes, and Reporting

Göstemeyer, G. (Berlin); Levey, C. (Dundee)

Recommendations

155 An Agreed Terminology for Carious Tissue Removal

Innes, N. (Dundee); Schwendicke, F. (Berlin); Frencken, J. (Nijmegen)

162 Clinical Recommendations on Carious Tissue Removal in Cavitated Lesions

Schwendicke, F. (Berlin); Frencken, J. (Nijmegen); Innes, N. (Dundee)

167 Caries Excavation: Evidence Gaps

Innes, N.; Robertson, M. (Dundee); Schwendicke, F. (Berlin)

172 Author Index

173 Subject Index 


\section{List of Contributors}

\section{Imad About}

Aix Marseille University, CNRS

ISM, Institute of Movement Sciences

FR Marseille (France)

E-Mail imad.about@univ-amu.fr

\section{Lars Bjørndal}

Section of Cariology and Endodontics

Department of Odontology

Faculty of Health and Medical Sciences

University of Copenhagen

Nørre Allé 20

DK-2200 Copenhagen (Denmark)

E-Mail labj@sund.ku.dk

\section{Uwe Blunck}

Charité Centre for Dental Medicine

Department for Operative and Preventive Dentistry

Assmannshauser Strasse 4-6

DE-14197 Berlin (Germany)

E-Mail uwe.blunck@charite.de

\section{Clarissa Bonifacio}

Department of Conservative Dentistry

Academic Centre for Dentistry Amsterdam - ACTA

Amsterdam (Netherlands)

E-Mail c.bonifacio@acta.nl

\section{Georg Conrads}

Division of Oral Microbiology and Immunology

Department for Operative Dentistry

Periodontology and Preventive Dentistry

RWTH Aachen University Hospital

Pauwelsstrasse 30

DE-52074 Aachen (Germany)

E-Mail gconrads@ukaachen.de
Sophie Doméjean

UFR d'Odontologie

2 rue de Braga

FR-63100 Clermont-Ferrand (France)

E-Mail sophie.domejean@uca.fr

\section{Margherita Fontana}

Cariology, Restorative Sciences and Endodontics

School of Dentistry, Room 2393

University of Michigan

1011 N University Avenue

Ann Arbor, MI 48109-1078 (USA)

E-Mailmfontan@umich.edu

\section{Jo Frencken}

Philips van Leijdenlaan 25

NL-6525 AX Nijmegen (The Netherlands)

E-Mail jo.frencken@radboudumc.nl

\section{Gerd Göstemeyer}

Charité Centre for Dental Medicine

Department for Operative and Preventive Dentistry

Assmannshauser Strasse 4-6

DE-14197 Berlin (Germany)

E-Mail gerd.goestemeyer@charite.de

\section{Brigitte Grosgogeat}

Université Lyon 1, UFR Odontologie, Laboratoire des Multimatériaux et Interfaces, UMR CNRS 5615, and Hospices Civils de Lyon, Service de Consultations et de Traitements Dentaires, FR-38670 Lyon (France)

E-Mail brigitte.grosgogeat@recherche.univ-lyon1.fr

Nicola Innes

School of Dentistry, University of Dundee

2 Park Place

Dundee DD1 4HR (UK)

E-Mail n.p.innes@dundee.ac.uk 


\section{Thomas Lamont}

School of Dentistry, University of Dundee

2 Park Place

Dundee DD1 4HR (UK)

E-Mail t.lamont@dundee.ac.uk

\section{Soraya Leal}

Campus Darcy Ribeiro, Faculdade de Ciências da Saúde Departamento de Odontologia

Universitdade de Brasília

Brasília, DF 70670-410 (Brazil)

E-Mail sorayaodt@yahoo.com

\section{Colin Levey}

School of Dentistry, University of Dundee

2 Park Place

Dundee DD1 4HR (UK)

E-Mail c.levey@dundee.ac.uk

\section{Adrian Lussi}

Department of Preventive, Restorative and

Pediatric Dentistry

University of Bern

Freiburgstrasse 7

$\mathrm{CH}-3010$ Bern (Switzerland)

E-Mail adrian.lussi@zmk.unibe.ch

\section{Klaus W. Neuhaus}

Department of Preventive

Restorative and Pediatric Dentistry

Freiburgstrasse 7

$\mathrm{CH}-3010$ Bern (Switzerland)

E-Mail klaus.neuhaus@zmk.unibe.ch

\section{Daniela Raggio}

Department of Orthodontics and Pediatric Dentistry

School of Dentistry, University of São Paulo

São Paulo (Brazil)

E-Mail danielar@usp.br

\section{David Ricketts}

School of Dentistry, University of Dundee

2 Park Place

Dundee DD1 4HR (UK)

E-Mail d.n.j.ricketts@dundee.ac.uk

\section{Mark Robertson}

School of Dentistry, University of Dundee

2 Park Place

Dundee DD1 4HR (UK)

E-Mail m.robertson@hotmail.co.uk

\section{Ruth M. Santamaría}

Department of Preventive and Pediatric Dentistry Ernst-Moritz-Arndt University of Greifswald

Rotgerbergstrasse 8

DE-17487 Greifswald (Germany)

E-Mail ruth.santamaria@uni-greifswald.de

\section{Falk Schwendicke}

Operative and Preventive Dentistry

Charité - Universitätsmedizin Berlin

Corporate Member of Freie Universität Berlin

Humboldt-Universität zu Berlin, and

Berlin Institute of Health

Assmannshauser Strasse 4-6

DE-14197 Berlin (Germany)

E-Mail falk.schwendicke@charite.de

\section{Guus van Strijp}

Department of Cariology Endodontology

Pedodontology

Academic Centre for Dentistry (ACTA)

University of Amsterdam and VU University Amsterdam

Gustav Mahlerlaan 3004

NL-1081 LA Amsterdam (The Netherlands)

E-Mail a.vstrijp@acta.nl

\section{Cor van Loveren}

Department of Cariology Endodontology

Pedodontology

Academic Centre for Dentistry (ACTA)

University of Amsterdam and VU University Amsterdam Gustav Mahlerlaan 3004

NL-1081 LA Amsterdam (The Netherlands)

E-Mail c.v.loveren@acta.nl 


\section{Foreword}

A monograph addresses a single subject and this book is about caries excavation - everyday dentistry for many. How should soft, infected dentine be managed? The authors have studied, discussed, and researched this question and distilled contemporary knowledge for you. Intriguingly, with one notable exception, it may not matter what you do. Brush, seal, or selectively remove, all have their place but with each you must understand what is being attempted and why.

So what is the exception? What must you not do? You must never pick up a sharp excavator or burr and remove soft tissue vigorously because this could damage the tooth and even prejudice its survival. Perversely, this might be precisely what you were taught to do in dental school! This just goes to show how research changes clinical practice and how important it is to keep up to date.

So read and enjoy the book!

Edwina Kidd, London

Em. Professor in Cariology 


\section{Preface}

There is a reason why medical researchers do their work. They wish to contribute to improving people's health and well-being through eradicating diseases, to improve existing treatments and change disease-causing behaviour, and much more, through the study of these areas.

An astronomically high number of medical publications appear in the literature monthly. The number of oral health-related publications is very high, too high for a dental practitioner to read them all. Some of these have a quality that leaves one wondering how the manuscript passed the review process. Others are of extremely good quality and provide new worthwhile information.

The scientific world is assisting medical professionals by producing systematic reviews and/ or meta-analyses on an ever-growing number of topics. A systematic review merely appraises the available evidence on a topic in the literature on the basis of research quality criteria and then draws conclusions. They are not designed to make recommendations on treatment. Therefore, these reviews and/or meta-analyses cannot be left on their own as the impacts of the individual results need to be merged to facilitate change, for example in improving (oral) health or aspects of it. It is like bricks that need cement to build a solid structure. A way of combining newly acquired knowledge into contemporary disease management concepts is to write a book, or in this particular case a monograph. Another way is to develop guidelines.
The current monograph was written by dedicated researchers who are experts in the various subfields of cariology and restorative dentistry. The chapters are built on evidence-based results and take the reader through the development of dental caries, assess the devices for diagnosing it in clinical practice and in an epidemiological setting, and provide new insights in the way a dentine carious cavity can be managed both from a tissue removal and a restoration point of view. Examples of dental tissue-preserving methods are presented and the necessity for sealing a dentine carious cavity with a quality restorative material is highlighted with ample evidence. Also, an update on how to conduct a randomised clinical trial is presented, and a chapter is included on terminology to support better verbal communication and interactions between members of the oral health profession from all corners of the world. The monograph concludes with recommendations and suggestions of areas in dentine carious cavity treatment that are not fully understood yet.

In essence, dental caries is a preventable, behaviour/life-style disease. It implies that members of the public do not need to go through the ordeal of drilling and filling teeth regularly as the generation following the Second World War had to undergo. At that time, oral health research was in its infancy. Over the past decades, oral science has yielded information that benefits the public. It is the duty of the oral health profession to em- 
brace philosophies of managing dental caries, such as the minimal intervention dentistry concept, which aims to keep healthy teeth healthy throughout life by preserving sound and remineralisable tooth tissue. The expectation in many parts of the world as people are getting older is that they wish to enjoy a well-functioning, painfree oral cavity. Therefore, tissue-saving procedures should be commonplace after caries prevention has failed, in order for the elderly to have a sufficient number of functioning teeth to assist them.

The idea for writing this monograph on the Evolution of Treating Cavitated Carious Lesions was born at the memorable congress of the European Organisation of Dental Research (ORCA) in Liverpool in 2014. It became operational first at the 2015 Leuven meeting, where the Internation- al Caries Consensus Cooperation (ICCC) was established. The ICCC published 4 papers in 2016 that form the basis of a number of chapters contained in the current monograph.

We wish the reader very many happy moments reading this work. We hope that this monograph finds its way to undergraduates in all dental schools and to postgraduate education courses around the world. The oral health profession has the knowledge and tools, as well as the duty to participate together with people/patients to "prevent restorations" and to "prevent root canal treatment and extraction on the basis of dental caries," and to prolong a healthy dentition into older age. Let's collectively do it.

Falk Schwendicke, Berlin Jo Frencken, Nijmegen

Nicola Innes, Dundee 
